() С. М. Зигуля, к.т.н., доцент, КП। ім. Ігоря Сікорського, Київ, Україна

\title{
ДОСЛІДЖЕННЯ ЗМІНИ ВЕЛИЧИНИ РАСТРОВОЇ КРАПКИ НА КРЕЙДОВАНОМУ ПАПЕРІ
}

Досліджено зміни величини растрової крапки на крейдованому папері. Встановлено можливу взаємодію параметрів шорсткості поверхні друкарського циліндра, його мікротвердість, товщину фарбового шару та тиску в друкарському процесі на величину растрової крапки.

Ключові слова: якість відбитка; математичне моделювання; Факторне планування; розтискування растрової крапки; офсетний друк; кольоровий відбиток.

\section{Постановка проблеми}

Ефективність дослідження растрової крапки в процесі друкування значною мірою залежить від технічних параметрів друкарської машини та можливості керування ними. Прогнозування величини растрової крапки потребує проведення великої кількості експериментів. Забезпечити достовірну інформацію та отримати найвигідніші співвідношення результатів дозволяють методи математичного планування.

Вплив на розтискування крапки значної кількості параметрів зумовило складні умови проходження процесу. На сьогодні механізм впливу $€$ недостатньо дослідженим тому було застосовано метод статистичного аналізу для зменшенням витрат часу на проведення досліджень та матеріальних затрат [1-3].
Аналіз попередніх

\section{досліджень}

Конкурентоздатність поліграфічної продукції $€$ досягненням високої якості. Поліграфічний рівень видань досить сильно зріс, завдяки зростанню технічного рівня поліграфічного обладнання, а саме додрукарського, формного, друкарського і брошурувально-палітурного. Крім цього, ставляться жорсткі вимоги замовників до якості виготовлення друкованої продукції. Враховуючи аналіз попередніх досліджень можна стверджувати, що стабільна якість це результат професійного впливу на неї [4].

Вимірювальними характеристиками кольорових зображень на відбитку, які можна об'єктивно оцінити є: забрудненість чистого кольору на відбитку відносна площа растрових елементів [5]; баланс по «сірому»; максимальна оптична густина; відтворення сірої та кольорової (за окремими

(c) 2018 p. 
друкарськими фарбами) шкал; інтервал оптичної густина; зміна оптичної густини; перехід фарб при багатофарбовому накладанні (трепінг) [6].

Для друкування визначення основних параметрів, які регулюються режимами технологічного процесу, змінення яких призводить до дефектів на друкарському відбитку, вважається не простим завданням.

Аналітичні моделі на основі повного факторного планування передбачають зміну величини розтискування растрової крапки в процесі двобічного друкування та дають змогу аналізувати параметри друкованого відбитка й керувати ними. Цей тип планів першого порядку, втілення якого відбувається через знаходження досліджуваної функції за використання всіх сполучених у певних рівнях варіювання складових.

\section{Мета роботи}

Отримання математичних моделей результатів розрахунку зміни величини растрової крапки на крейдованому папері, а також показ методом багатофакторного планування варіантів взаємодії технологічних параметрів: товщини фарби й величини тиску в процесі друкування та мікрогеометрії поверхні друкарського циліндра й мікротвердості.

\section{Результати проведених досліджень}

Важливою умовою планування експерименту $є$ якість початкової інформації. Тому було дотримано всіх важливих умов теорії планування, а саме усунення систематичних похибок; дотримання плану та методики; прове- дення повторних експериментів в ідентичних умовах; використання результатів цих дослідів; під час проведення дослідів вибір об'єктів відбувався у випадковому порядку, що нівелювало систематичні помилки; параметри, які використовувалися мали однорідні властивості [7-9].

Параметри якості поверхні друкарського циліндра було отримано після його обробки методом вібраційного накатування з утворенням повністю регулярного мікрорельєфу гексагонального типу ввігнутої форми та хромування, було отримано значення мікротвердості (М), шорсткості поверхні $\left(\mathrm{R}_{\mathrm{a}}\right)$, а також тиск у процесі друкування (P), товщину фарби (Т). Використовуючи метод експертної оцінки ми отримали середній апріорний ранжируваний ряд факторів, що впливають на розтискування растрової крапки, а також визначили границі зміни цих факторів, методи та точність їх вимірювання.

Після аналізу та розміщення величин у певному порядку за ступенем важливості матриця планування склалася 3 таких чинників: шорсткість поверхні $\left(R_{a}\right)-X_{1}$, мікротвердість $(M)-X_{2}$, товщина фарбового шару $(T)-X_{3}$, тиск в друкарському процесі (P) $\mathrm{X}_{4}$ [10].

Опрацювання результатів було проведено відповідно:

а) за критерієм Кохрена робилася перевірка однорідності дисперсій та розрахунок дисперсії відтворюваності:

$$
\mathrm{G}^{\mathrm{e \kappa cn}}=\frac{\mathrm{S}_{\max }^{2}}{\sum_{\mathrm{u}=1}^{\mathrm{N}} \mathrm{s}_{\mathrm{u}}^{2}}
$$


де $\mathrm{s}_{\max }^{2}$ - максимальна з дис-

персій; $\mathrm{s}_{\mathrm{u}}^{2}$ - дисперсії розраховані для кожного досліду [10].

Про однорідність дисперсій вказувало досягнення умови

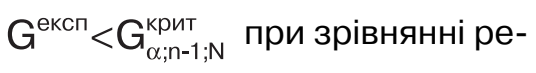

зультатів експериментів 3 критичним значенням.

б) за критерієм Стьюдента робилася перевірка вагомості коефіцієнта регресії (для ортонормованої матриці):

$$
\mathrm{t}=\frac{\mathrm{b}_{\mathrm{i}} \sqrt{\mathrm{n}}}{\mathrm{s}_{\text {відт }} \sqrt{\mathrm{c}_{\mathrm{ii}}}},
$$

де $\mathrm{s}_{\text {відт }}$ - середнє квадратичне відхилення; $\mathrm{c}_{\mathrm{ii}}$ - діагональний елемент матриці дисперсій.

Якщо виконується умова $\mathrm{t}>\mathrm{t}_{\alpha, v_{\text {відт }}}$, то коефіцієнт вагомий [10].

Аналіз властивостей даної моделі проводився за основними показниками, а саме інформативність, адекватність, стійкість. Інформативність оцінювалась за величиною множинного коефі- цієнта кореляції R, а саме коефіціент кореляції між експериментальним значенням відгуку та значенням відгуку, розрахованим за моделлю. Розрахунок виконувався за формулою:

$$
\mathrm{R}^{2}=\mathrm{Q}_{\mathrm{R}} / \mathrm{Q}_{\text {заг }}
$$

де $\mathrm{R}^{2}$ - величина, яка показує частку загальної суми квадратів, що пояснюється моделлю.

Значення $\mathrm{R}$ повинно бути якнайближче до одиниці.

Адекватність оцінювалась за критерієм Фішера, коли умова $\mathrm{F}^{\mathrm{eкcn}}<\mathrm{F}^{\text {крит }}$ виконувалась та різниця дисперсій була незначною, модель вважалась адекватною.

Стійкість моделі аналізувалась за мультиколінеарністю й числом обумовленості cond. Ідеальне значення cond дорівнює 1.

Діаграма розподілу свідчить про найбільший вплив незалежних факторів. Сила впливу визначається як частина регресора, який приймає участь. Він дорівнює відношенню суми квадратів до загальної суми квадратів. За нормальних обставин сила впливу ефектів зменшується відповідно до експоненціальної залежності.

Особливо важливим етапом $€$ визначення факторів, які в тій

Дані визначених режимів

\begin{tabular}{|l|c|c|c|c|}
\hline Характеристика & $\begin{array}{c}\text { Шорсткість } \\
\text { поверхні, }\left(\mathrm{X}_{1}\right)\end{array}$ & $\begin{array}{c}\text { Мікротвер- } \\
\text { дість, МПа }\left(\mathrm{X}_{2}\right)\end{array}$ & $\begin{array}{c}\text { Товщина } \\
\text { фарбового } \\
\text { шару, мкм }\left(\mathrm{X}_{3}\right)\end{array}$ & $\begin{array}{c}\text { Тиск у процесі } \\
\text { друкування, } \\
\text { МПа }\left(\mathrm{X}_{4}\right)\end{array}$ \\
\hline Нижній рівень & 0,63 & 6440 & 0,7 & 0,4 \\
\hline Середній рівень & 0,94 & 7950 & 2,1 & 1,2 \\
\hline Верхній рівень & 1,25 & 9460 & 3,5 & 2,0 \\
\hline Інтервал & 0,31 & 1510 & 1,4 & 0,8 \\
\hline
\end{tabular}


чи іншій мірі впливають на технологічний процес. Залежною величиною в даному експерименті $\epsilon$ параметр якості кольорового зображення, а величинами, які їі змінюють $\mathrm{X}_{1}, \mathrm{X}_{2}, \mathrm{X}_{3}, \mathrm{X}_{4}$. Кодування факторів надає можливість переведення факторів у безрозмірні величини, забезпечує порівняння та побудову ортогональної матриці.

Після виведення математичних моделей і отримання експериментальних значень проведено обробку статистичних характеристик, яка підтвердила, що модель $€$ адекватною так як експериментальне значення F-критерію дорівнює 3,351 і є меншим за критичне значення F-критерію, яке дорівнює 3,374 , стійкість моделі дає можливість підтвердити її оригінальність, тобто Cond $=1$, значення параметра для критерію Бокса - Вецаа дорівнює 3, що має добрі описові та інформаційні характеристики. Дисперсії експериментів однорідні.

Окреслюючи результат дослідження можна побачити неодна- ковий характер впливу змінних факторів на параметр якості відбитка. Так, при збільшенні величини шорсткості поверхні друкарського циліндра та при зміні мікротвердості (за умови, що інші фактори мали встановлену величину) параметр розтискування крапки зростав (рис. 2).

Параметр розтискування крапки зростав, в межах допустимих норм, у випадках коли: збільшувалась величина шорсткості поверхні друкарського циліндра та при зміні мікротвердості й зміні товщини шару фарби (за умови, що решта факторів мали сталу величину). Співмірно мінялась величина розтискування крапки, коли збільшувалась шорсткість поверхні й тиск, сталими були мікротвердість, товщина шару фарби, а також при збільшенні товщини фарби і тиску, а шорсткість поверхні і мікротвердість - фіксовані. Причому взаємодії шорсткості поверхні й тиску, у першому випадку, а також товщини фарби й тиску, у другому випадку не спостерігалось. Показник розтискування

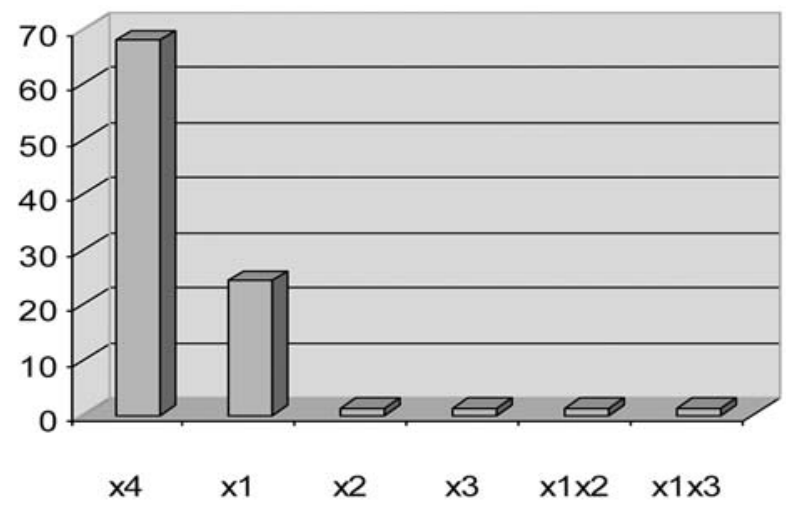

Рис. 1. Діаграма розподілу незалежних факторів 
крапки мав сталу величину при збільшенні мікротвердості й тиску, а зміна показника мікротвердості не має впливу розтискування крапки (рис. 3).

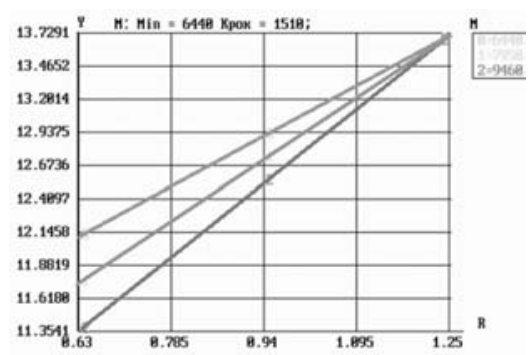

a

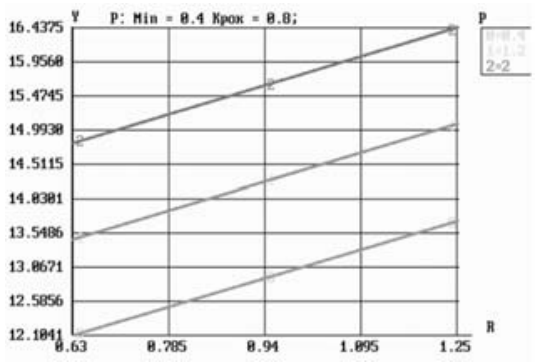

B

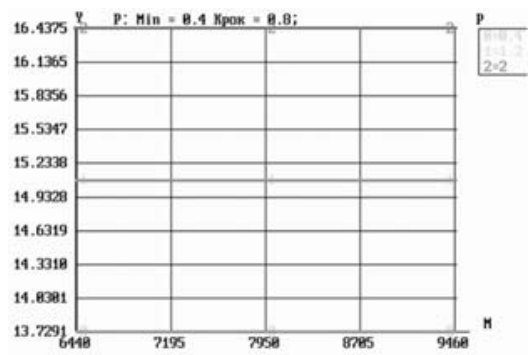

д

\section{Висновки}

Планування багатофакторного експерименту дало змогу отримати модель розрахунку растрової крапки на крейдова-

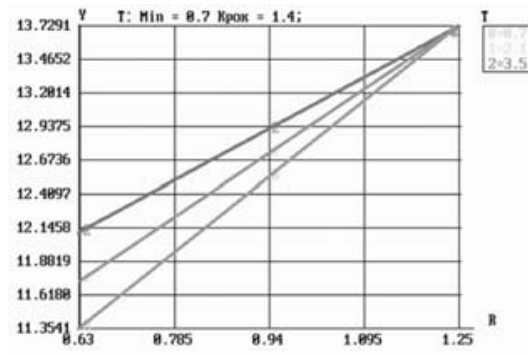

б

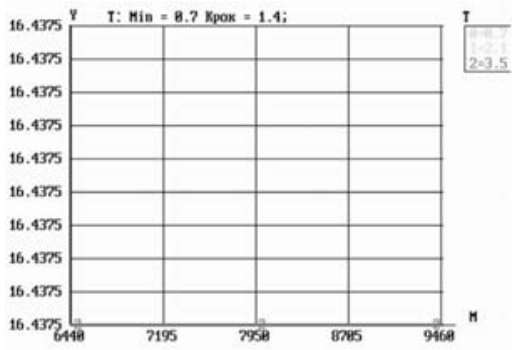

$\Gamma$

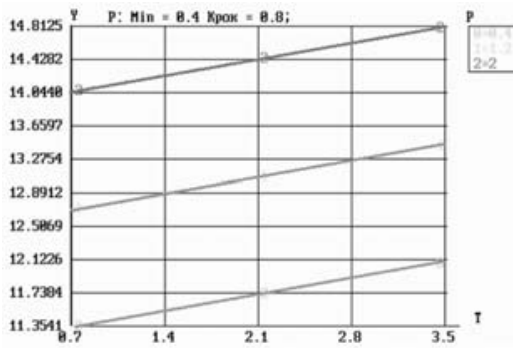

e

Рис. 2. Вплив досліджуваних факторів на зміну величини растрової крапки: а - шорсткості поверхні та мікротвердості; б - шорсткості поверхні та товщини шару фарби; в - шорсткості поверхні та тиску друкуванні; г - мікротвердості та товщини шару фарби; д - мікротвердості та тиску в друкарському процесі; е - товщини шару фарби та тиску в друкарському процесі 
ному папері та адекватно описати взаємозалежність таких керованих факторів: шорсткість поверхні, мікротвердість, товщина фарбового шару й тиску у друкарському процесі.

Розроблення математичної моделі за планом повного факторного експерименту дає можливість отримати парні залежності факторів і в подальшому побудувати їхні поверхні відгуків. Це дозволяє встановити зв'язок між вхідними параметрами запропонованого комплексного технологічного процесу та парамет- рами якості друкованого відбитка.

Аналіз факторних просторів залежності параметру розтискування крапки, показує, що на величину розтискування крапки впливає: мікрогеометрія поверхні (шорсткість) друкарського циліндра, товщина фарбового шару, а також тиск при друкуванні. 3 рисунку 3, а-г видно, що відбуваються підйоми поверхонь відгуків зі зростанням мікрогеометрії поверхні друкарського циліндра (шорсткості), збільшенням товщини фарбового шару та тиску при друкуванні.

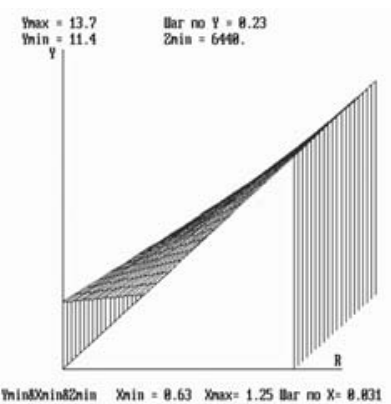

a

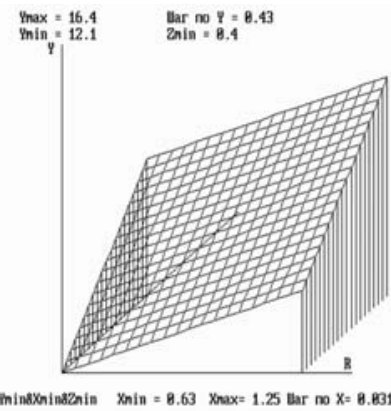

B
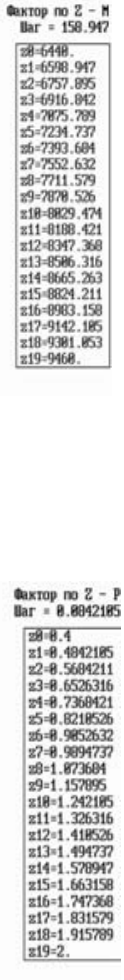

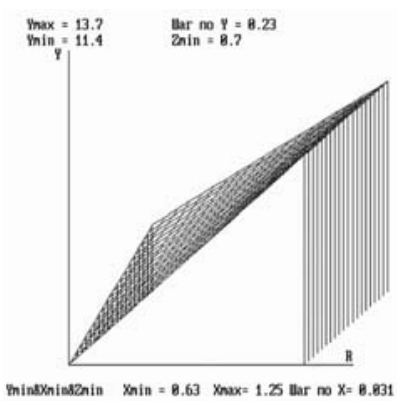

б
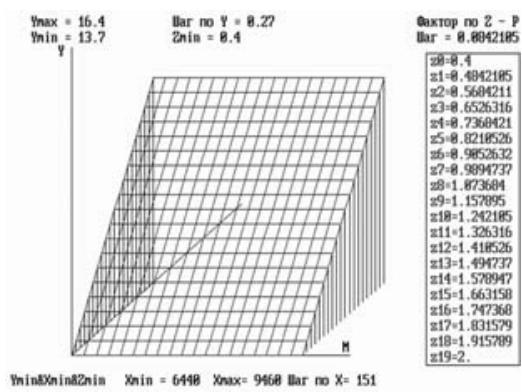

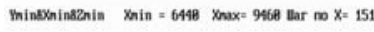

$\Gamma$

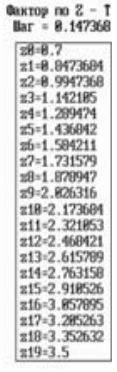

Рис. 3. Просторові зображення відгуків: $a-$ функції $\mathrm{y}=\mathrm{f}\left(\mathrm{X}_{1}, \mathrm{X}_{2}\right)$; б - функції $\mathrm{y}=\mathrm{f}\left(\mathrm{X}_{1}, \mathrm{X}_{3}\right)$; в - функції $\mathrm{y}=\mathrm{f}\left(\mathrm{X}_{1}, \mathrm{X}_{4}\right) ;$; — функції $\mathrm{y}=\mathrm{f}\left(\mathrm{X}_{2}, \mathrm{X}_{4}\right)$ 


\section{Список використаної літератури}

1. Сторожук О. А. Моделирование и вариантное прогнозирование развития техники / О. А. Сторожук. М.: Машиностроение, 2005. 252 с.

2. Струтинський В. Б. Математичне моделювання процесів та систем механіки: підручник / В. Б. Струтинський. Житомир: Житомир. інженер.техн. ін-т, 2001. $612 \mathrm{c}$.

3. Суслов А. Г. Качество поверхностного слоя деталей машин / А. Г. Суслов. М.: Машиностроение, 2000. 320 с.

4. Сборник статей по полиграфии / под. ред. А. В. Макарова, С. А. Седова, В. И. Шлямина. М.: Группа компаний «Танзор», 2011. 132 с.

5. Барковский Е. В. Моделирование процесса растискивания с учетом влияния преломления луча / Е. В. Барковский, Д. М. Медяк // Труды БГТУ. 2013. № 8. C. 52-54.

6. Стефанов С. Оценка печати оттисков [Текст] / С. Стефанов. М.: Репроцентр, 2003. 38 с.

7. ДСТУ ГОСТ 25142:2009 «Шероховатость поверхности. Термины и определения». Введ. 1983-01-01. М.: Изд-во стандартов, 1981. 22 с.

8. Душинський В. В. Основи наукових досліджень. Теорія та практикум 3 програмним забезпеченням: навч. посіб. Київ: НТУУ «КПІ», 1998. 408 с.

9. Радько О. В. Оптимізація технологічних процесів формування захисних структур триботехнічного призначення // Проблеми тертя та зношування: наук.-техн. зб. Київ: Вид-во НАУ «НАУ-друк», 2011. Вип. 55. С. 173-181.

10. Лапач С. Н. Статистические методы в медико-биологических исследованиях с использованием Excel / С. Н. Лапач, А. В. Чубенко, П. Н. Бабич. Киев: Морион, 2001. 408 с.

\section{References}

1. Storozhuk, O. A. (2005). Modelirovanie $i$ variantnoe prognozirovanie razvitiya tekhniki. Moscow: Mashinostroenie, 252 p. [in Russian].

2. Strutynskyi, V. B. (2001). Matematychne modeliuvannia protsesiv ta system mekhaniky. Zhytomyr: Zhytomyr. inzhener.-tekhn. in-t, 612 p. [in Ukrainian].

3. Suslov, A. G. (2000). Kachestvo poverkhnostnogo sloya detaley mashin. Moscow: Mashinostroenie, 320 p. [in Russian].

4. (2011). Sbornik statey po poligrafii. Moscow: Gruppa kompaniy 'Tanzor', 132 p. [in Russian].

5. Barkovskiy, E. V. \& Medyak, D. M. (2013). Modelirovanie protsessa rastiskivaniya s uchetom vliyaniya prelomleniya lucha. Journal of Trudy BGTU, 8, 52-54 [in Russian].

6. Stefanov, S. (2003). Otsenka pechati ottiskov. Moscow: Reprotsentr, 38 p. [in Russian].

7. DSTU GOST 25142:2009 'Sherokhovatost' poverkhnosti. Terminy i opredeleniya'. Published 1983.01.01. Moscow: Izd-vo standartov, 22 p. [in Russian].

8. Dushynskyi, V. V. (1998). Osnovy naukovykh doslidzhen. Teoriia ta praktykum z prohramnym zabezpechenniam. Kyiv: NTUU 'KPI', 408 p. [in Ukrainian].

9. Radko, O. V. (2011). Optymizatsiia tekhnolohichnykh protsesiv formuvannia zakhysnykh struktur trybotekhnichnoho pryznachennia. Journal of Problemy tertia ta znoshuvannia. Kyiv: Vyd-vo NAU 'NAU-druk', 55, 173-181 [in Ukrainian]. 


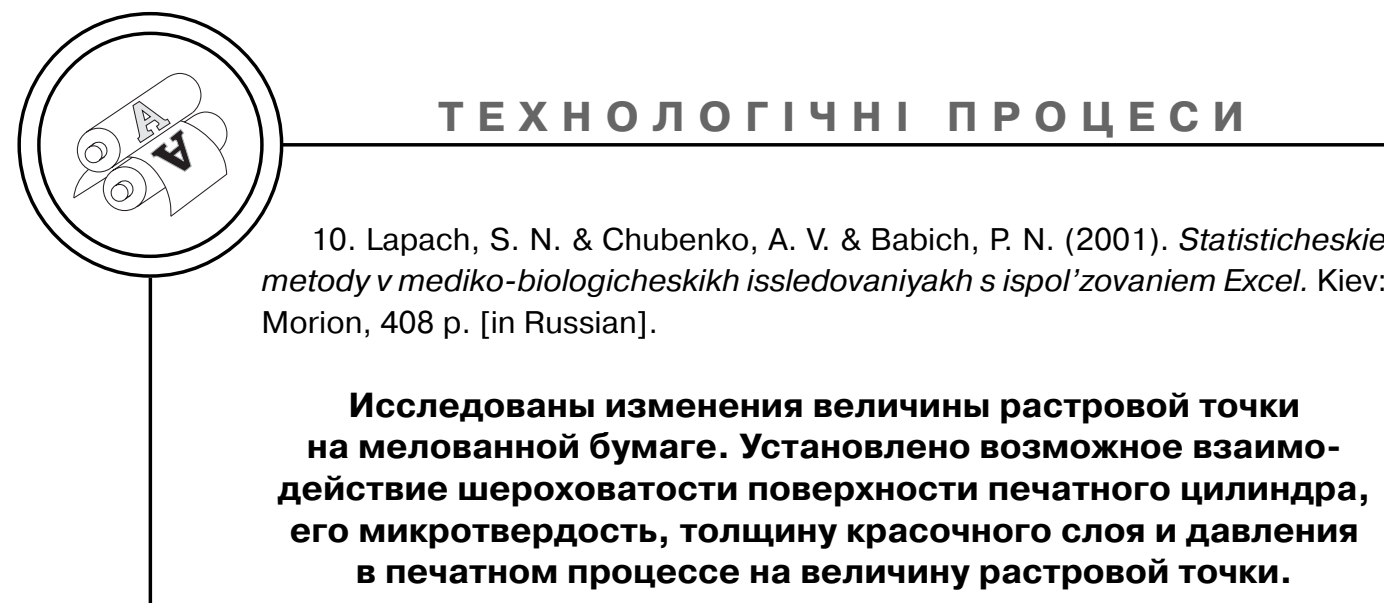

Ключевые слова: качество оттиска; математическое моделирование; факторное планирование; растискивание растровой точки; офсетная печать; цветной оттиск.

The research's efficiency the raster dot in the printing process is considered in the article. Changes in the color form quality depend to a large extent on the printing machine technical specifications and the ability to control them. Objectively, the color estimated characteristic on the form is the raster elements relative area. To predict the raster dot's value, we need to conduct a large scale of experiments to provide reliable information and get the most beneficial results. Mathematical models based on factor planning of experiments allowing predict the raster dot's unwinding magnitude in the printing process and determine the possible interaction of the roughness parameters the printing cylinder surface, its microhardness, the ink layer thickness and pressure in the printing process, and also allow to control the form quality parameters. This method is the most common type of first-order plans, the realization occurs because of finding the researched function for all possible combinations of factors variation levels.

Keywords: imprint quality; mathematical modeling; factorial planning; dot gain; offset printing; color imprint. 